Received: 18.10 .2020

Revised: 16.12 .2020

Accepted: 18.12 .2020

DOI: $10.17804 / 2410-9908.2020 .6 .054-061$

\title{
IMPLANTS AND BONE TECHNOLOGY WITH THE USE OF DOPED CALCIUM CARBONATE PHOSPHATES
}

\author{
L. F. Koroleva ${ }^{1, a^{*}}$, L. P. Larionov ${ }^{2, \text { b) }}$ and M. N. Dobrinskaya ${ }^{2, c)}$ \\ ${ }^{1}$ Institute of Engineering Science, Ural Branch of the Russian Academy of Sciences, \\ 34 Komsomolskaya St., Ekaterinburg, 620049, Russian Federation \\ ${ }^{2}$ Department of Pharmacology and Clinical Pharmacology, \\ Ural State Medical University, Russian Federation \\ a) iD https://orcid.org/0000-0001-6650-7494 lq@imach.uran.ru ; \\ b) leonid-larionov@ mail.ru; \\ c) iD http://orcid.org/0000-0001-9208-9417 maria-nd@mail.ru \\ *Corresponding author. E-mail: \\ Address for correspondence: 34 Komsomolskaya St., Ekaterinburg, 620049, Russian Federation \\ Tel.: +7 (343) 37535 76; fax: +7 (343) 3745330
}

The possibility of obtaining an alloplastic biomaterial for the implant based on doped calcium carbonate-phosphates and polycaprolactone is studied. Nanocrystalline calcium carbonatephosphate doped with cations of iron, magnesium, potassium, zinc, manganese, and silicon intended for bone repair by drug delivery is investigated. Histological studies have revealed that samples after 60 days in a living organism are covered by a connective tissue capsule. The formation of blood vessels and nerve endings is observed in the capsule.

Keywords: biocompatible materials, dopes, calcium carbonate-phosphate, implant, osteogenesis, bone and dental tissues.

\section{Introduction}

The creation of new polymer composites for to replacing damaged or missing fragments of the skeleton, as well as the regeneration of bone tissue in orthopedics and cranio-maxillofacial surgery, is now one of the most intensively developing trends in biomedical materials science. The problem of replacing bone tissue defects in implantology and orthopedics has acquired a new dimension with the appearance of synthetic highly resorbable biomaterials.

According to Dr. Larry Hench, the inventor of bioglass [1], the development of bone substitutes is a revolutionary step in the development of humanity. This area of material science is referred to as bioceramics; it covers materials for implants in traumatology and orthopedics, sealing materials in dental medicine, implants in maxillofacial surgery, and medical cosmetics. Bone tissue engineering offers an alternative approach for the treatment and rehabilitation of bone defects by stimulating bone formation from surrounding tissues. Cells and growth factors are important elements in tissue engineering, which depend on the function of the localization of the tissue defect.

However, the tasks of modern medicine and biotechnology are not only creating materials and replacing bone tissue and organs, but also the synthesis of biologically active substances contributing to complete tissue regeneration and maintenance of the necessary functions of an organism.

Implants are introduced into clinical practice of ceramics, polymers, metals, carbon, and composite materials [2-11]. The physical-chemical and biological properties of an artificial bonereplacement material should be close to those of normal bone tissue, they should be osteocompati- 
ble and optimizing the flow of reparative processes. The experimental study of the synthesis of inorganic calcium phosphates, i.e. osteoconductivity of ceramics for bone recovery capable of creating the starting condition for bone growth, is one of the most current trends. Statistically, the deficiency of bone tissue for implantation aimed at rehabilitation activities takes place in almost $40 \%$ of cases.

It is very important to ensure the physiological process, load balancing, the durability and aesthetic look of the structure. For this purpose, living tissue around the implant must be restored, the system size must be determined correctly, and the implant must be positioned with due regard for anatomical features. Today, bone is used for transplantation; this technique provides easy implantation, and it is almost all natural. This process is called autotransplantation. Besides, alloplastic bone materials are divided into groups depending on the origin. For autogenous materials, the source of the material is the patient; allogeneic materials are obtained from the tissues of another person; xenogeneic donor materials are obtained from animals. A alloplastic materials are made synthetically.

Osteoconductive materials promote bone regeneration by direct stimulation of the transformation of undifferentiated mesenchyme cells into osteoblasts, i.e. osteoconductive materials directly affect bone growth. Osteoconductive materials are used as a matrix, or a skeleton, which is bone neoplasm, and they serve for further differentiation. The osteodifferentiated material is inert and generally non-resorptive, and it is used for filling cavities.

Biocompatible bone material, which can be considered sufficiently inert and fairly osteoinductive and active relative to the bioactivity and osteoconductivity for alloplastic materials with complete resorption, possesses osteoconductive properties. Materials of choice are those with biodegradation time, i.e. the time of new bone formation, of 6 to 12 months. Their use does not form an osteoid; therefore, it is applicable in implantology.

Bioactive materials with partial biodegradation are osteoconductive and osteoneutral. Materials with partial dissipation belong to the osteoinductal classification as completely insoluble. The main characteristic of the alloplastic bone materials is solubility: they are divided into soluble and insoluble ones. They include specific chemical compounds, namely hydroxyapatite, calcium carbonate, polymers, bioactive glass, calcium sulfate, and alpha- and beta-tricalcium phosphates.

The problem of filling bone tissue defects in implantology and orthopedics acquires a new vision with the appearance of synthetic soluble biomaterials. These materials include calcium carbonate phosphates. For example, in order to obtain a soluble implant, one can use a polycaprolactone material applied in surgery for sutures as an easily absorbable one. When mixed with calcium carbonate phosphate, it can be a good alloplastic biocompatible material.

Traditionally, in cases of bone damage, doctors use metal implants for bone replacement. This method has several disadvantages; namely, sometimes the metal corrodes or it is rejected from the patient's body. Besides, natural bone implants need to be extracted from the body; this is an additional risk of complications after surgery. Thus, Pranav Soman, a bioengineer, and his colleagues from Syracuse University offered a technology for creating biodegradable implants based on polycaprolactone. This material has a low melting temperature (about $60{ }^{\circ} \mathrm{C}$ ), and it is widely used in $3 \mathrm{D}$ prototyping. Polycaprolactone is used in medicine as a suture material, as a component of capsules for medicine packaging, and as a composition for root canal sealing.

The advantage of the hardening of bone and tooth tissues in a person of any age with the transportation of substances through the skin and the restoration of the bone fracture in a critically short time over other biomaterials is described in [12]. A transdermal biomaterial based on doped nanocrystalline $\mathrm{Fe}^{2+}, \mathrm{Mg}^{2}, \mathrm{Zn}^{2+}, \mathrm{K}^{+}, \mathrm{Si}^{4+}$, and $\mathrm{Mn}^{2+}$ calcium carbonate phosphates can be considered new-generation medicinal substances.

3D printing technology developed by Soman and his colleagues allows one to create solid porous polymer skeletons. Next, the structure of bone cells placed into the GelMA hydrogel is filled. These cells are capable of reproducing hydroxyapatite of primary mineral content in human 
bones. The implant is subjected to ultraviolet radiation thereafter. According to Soman, polycaprolactone dissolves within a year, leaving bone tissue of the necessary form. The polymer construction creates a framework for growing bones and gradually dissolves without requiring surgery for prosthesis removal.

The method is now being tested on mice. Scientists suppose that, in the future, bones can be grown this way, with the use of the patient's own stem cells. This will reduce the risk of tissue rejection. 3D printing of human body tissues is indispensable in the situations when donor tissue is unavailable.

In December 2016 Roscosmos announced a plan to deliver such a printer to the International Space Station (ISS). On December 3, 2018 Oleg Kononenko, a Russian spaceman arrived at the ISS by the Soyuz MS-11 spacecraft and started an experiment on 3D bioprinting of living tissue. The first results of the experiment have been obtained by now; namely, an organ construct of a mouse thyroid gland has been created in zero gravity.

The paper deals with the effect of nanocrystalline calcium carbonate phosphate doped with cations of iron, magnesium, potassium, zinc, manganese, and silicon, which is intended for bone repair by drug delivery; the possibility of obtaining an alloplastic biomaterial for an implant based on doped calcium carbonate phosphates is studied.

\section{Materials and Methods}

Calcium carbonate phosphate samples doped with microelements were prepared with the use of three $\mathrm{CaCO}_{3}$ polymorphs: calcite (rhombohedral structure), vaterite (hexagonal structure), and aragonite (orthorhombic structure). The latter two phases are known to be metastable [13].

Calcium carbonate phosphates were precipitated by orthophosphoric acid added to a calcium carbonate suspension in a solution of ammonium bicarbonate and ammonium chloride (2 M) at 45 to $55^{\circ} \mathrm{C}$. The $\mathrm{pH}$ of the solution was 5.2 to 6.5 , depending on the $\mathrm{Ca} / \mathrm{P}$ molar ratio $(1.55-1.67)$. Doping cations were added during calcium carbonate precipitation: $\mathrm{Fe}^{2+}$ and $\mathrm{Mg}^{2+}, 0.01-0.06 ; \mathrm{Zn}^{2+}$, 0.00015-0.002; $\mathrm{K}^{+}, 0.05-0.3 ; \mathrm{SiO}_{2}, 0.0002-0.006 ;$ and $\mathrm{Mn}^{2+} \mathrm{mol} \%$.

The thus-obtained samples were characterized by X-ray diffraction (XRD) (CuKa radiation; a Stadi-P diffractometer for diffraction peak identification using the JCPDS-ICDD PDF2 database), IR spectroscopy (a Shimadzu JR-475 spectrophotometer, the KBr disk method). The elemental composition was determined by the X-ray fluorescence analysis (an EDX-900HS energy dispersive spectrometer) [14-20].

Polycaprolactone $\left[-\left(\mathrm{CH}_{2}\right)_{5}-\mathrm{COOH}-\right]_{\mathrm{n}}$ was used for implant production. The following mixture of polycaprolactone with doped calcium carbonate phosphate was obtained for the study: $5 \%, 10 \%$, and $15 \%$. The polycaprolactone had been heated in water to the softening temperature (70 to $\left.80{ }^{\circ} \mathrm{C}\right)$.

\section{Results and Discussion}

The reactions of the synthesis of doped calcium carbonate phosphates described in [13-16] include several initial compounds, such as calcium carbonate of three polymorphic crystal forms (calcite, aragonite, and vaterite), orthophosphoric acid, ammonium chloride, ammonium hydroxide, and living organism microelements $\left(\mathrm{K}^{+}, \mathrm{Mg}^{2+}, \mathrm{Fe}^{2+}, \mathrm{Zn}^{2+}, \mathrm{Mn}^{2+}, \mathrm{Li}^{+}\right.$, and $\left.\mathrm{SiO}_{2}\right)$. The formation of complex $\mathrm{M}_{\mathrm{g}-\mathrm{x}} \mathrm{M}_{\mathrm{x}}(\mathrm{OH})_{2}\left[\left(\mathrm{CO}_{3}\right)_{\mathrm{x}-2} \cdot \mathrm{H}_{2} \mathrm{O}\right]$ compounds is typical for transition elements. However, provided that the concentration of cations $\left(\mathrm{NH}_{4}{ }^{+}\right.$in our case) exceeds the concentration of the divalent cation by an order of magnitude and that the crystal lattice of the synthesized dyad compounds is defected, one can assume the appearance of such intermediate complexes. For example, in an ammonium hydroxide environment, three polymorphic forms of $\mathrm{CaCO}_{3}$ can make ammonium metastable hydroxycarbonate complexes according to the following scheme: 


$$
\mathrm{CaCO} 3+\mathrm{NH} 4 \mathrm{OH} \rightleftarrows \mathrm{NH} 4 \mathrm{CaCO} 3 \mathrm{OH} \text {. }
$$

The formation of three types of crystal structures of calcium carbonate (in the environment of ammonium hydroxide and ammonium chloride) is typical for the reaction (1): calcite, vaterite, and aragonite; it has been proved by the XRD data. Under the action of orthophosphoric acid in the presence of silicon dioxide and magnesium cations, carbonate in the phosphate group is replaced by the formation of $\mathrm{CaPO}_{3}(\mathrm{OH})$ or $\mathrm{CaHPO}_{4}$ (brushite) according to the reaction

$$
\mathrm{NH}_{4} \mathrm{CaCO}_{3} \mathrm{OH}+\mathrm{H}_{3} \mathrm{PO}_{4}=\mathrm{CaPO}_{3} \mathrm{OH}+\mathrm{NH}_{3}+\mathrm{CO}_{2}+2 \mathrm{H}_{2} \mathrm{O}
$$

The next stage in the presence of such doping microelements as $\mathrm{K}^{+}, \mathrm{Mg}^{2+}, \mathrm{Fe}^{2+}, \mathrm{Zn}^{2+}, \mathrm{Mn}^{2+}$, and $\mathrm{SiO}_{2}$ is the formation of hydroxy-chlorapatites according to the following scheme:

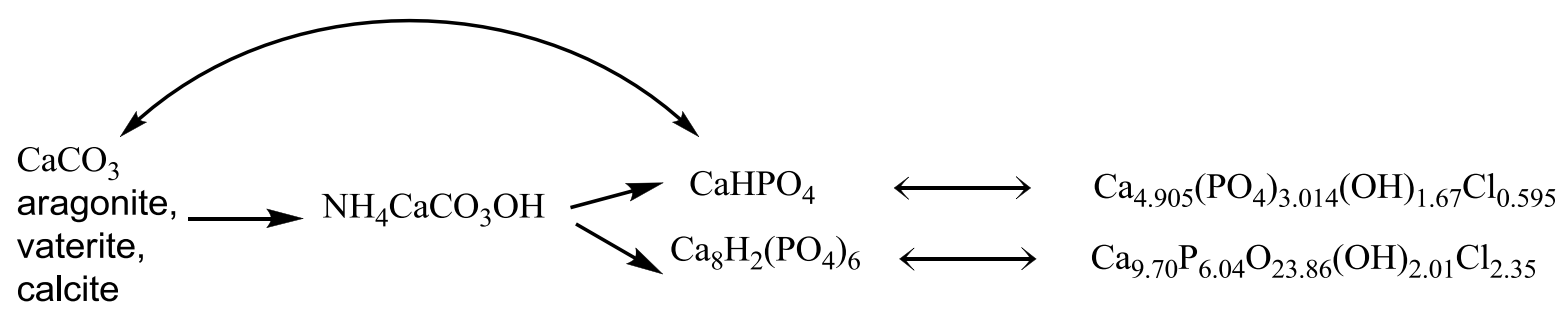

The behavior of the concentration of calcite, vaterite, and aragonite, as well as brushite and hydroxy-chlorapatites, in reaction products during the synthesis of calcium carbonate phosphate for reaction with $\mathrm{K}^{+}, \mathrm{Mg}^{2+}, \mathrm{Fe}^{2+}, \mathrm{Zn}^{2+}, \mathrm{Mn}^{2+}$, and $\mathrm{SiO}_{2}$ is shown in Fig. 1.

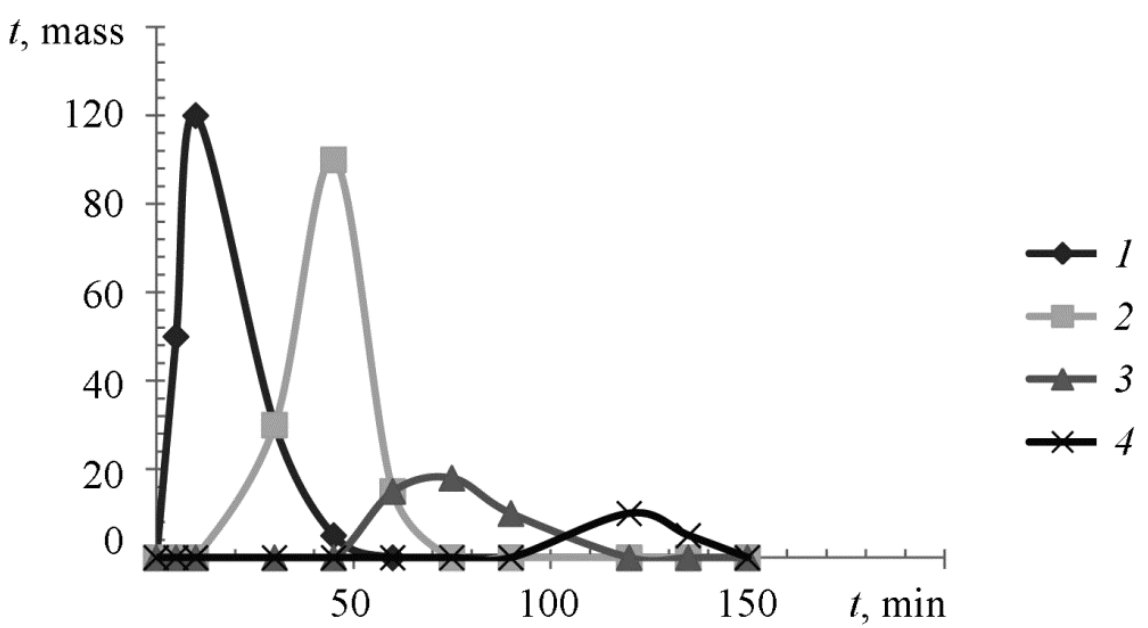

Fig. 1. The behavior of the concentration of calcite, vaterite, and aragonite (1), brushite (2), hydroxy-chlorapatites (3), and calcite (4) in reaction products during the synthesis of doped calcium carbonate phosphate for reaction with $\mathrm{K}^{+}, \mathrm{Mg}^{2+}, \mathrm{Fe}^{2+}, \mathrm{Zn}^{2+}, \mathrm{Mn}^{2+}, \mathrm{SiO}_{2}$

The animals ( 5 Wistar male rats) were assigned to the following five test groups: group I received a mixture of polycaprolactone with 0 mass $\%$ of doped calcium carbonate phosphate for the research; group II received a mixture of polycaprolactone with 5 mass \% of doped calcium carbonate phosphate; group III received a mixture of polycaprolactone with 5 mass $\%$ of doped calcium carbonate phosphate. The samples under the skin and muscular tissue of the laboratory rats showed the biological compatibility of the substances. The electron microscope images of the subcutaneous samples are shown in Fig. 2. Sixty days after the subcutaneous and intramuscular implan- 
tation of the samples, no signs of inflammation were detected. A thin and elastic capsule appeared around the implanted samples (Fig. 3).

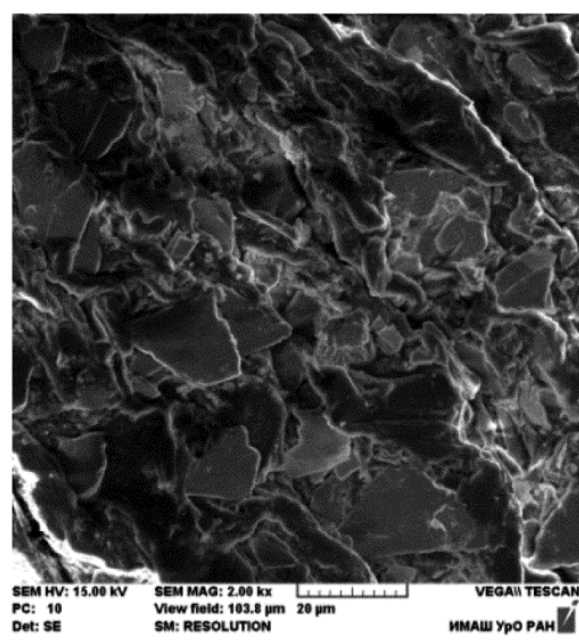

a

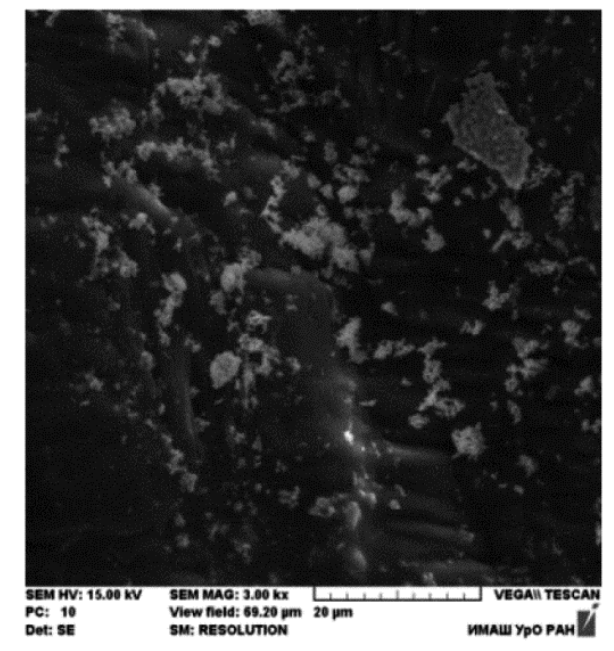

b

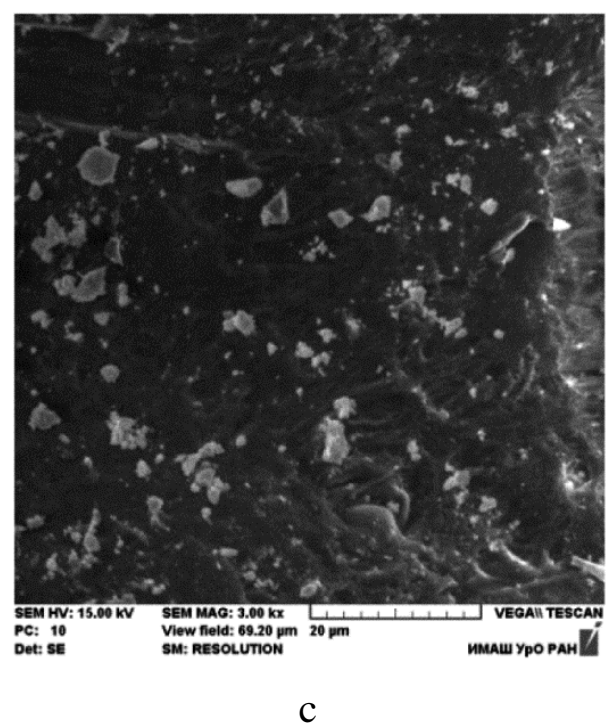

Fig. 2. Scans of electron micrographs of the samples of polycaprolactone mixed with doped calcium carbonate phosphate: $0 \%$ (a); $5 \%$ (b); $10 \%$ (c)

According to histological studies, samples obtained by mixing polycaprolactone and doped calcium carbonate phosphates in the amount of 5 to $10 \%$ are the same on a resorptive biomaterial. In this regard, the biomaterial can be recommended to be used as alloplastic implants. The formation of samples transported by the film, i.e. tubule capsules, occurs without any consequences in the form of soft tissue inflammation. The formation of blood vessels and nerve endings is observed (Fig. 4) in this capsule. 


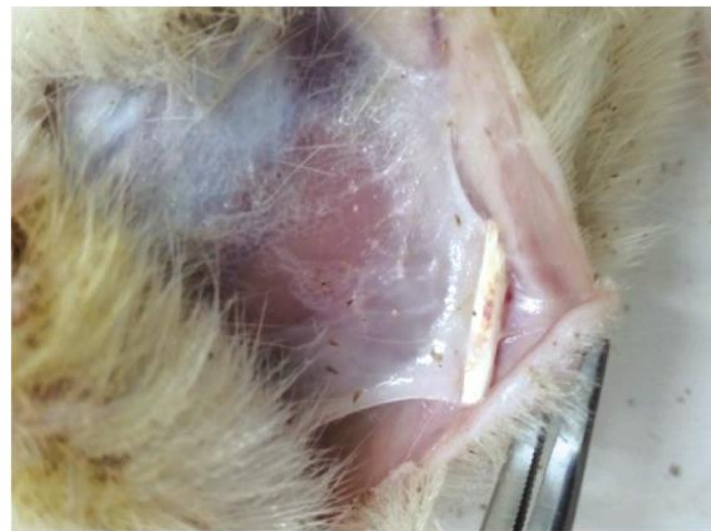

a

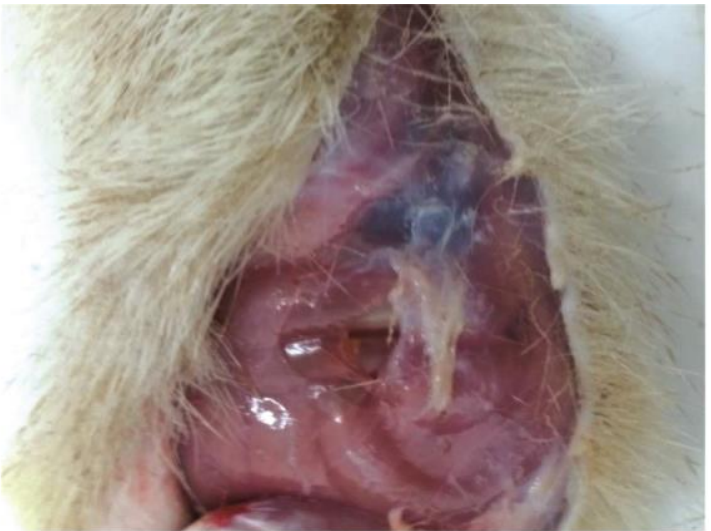

b

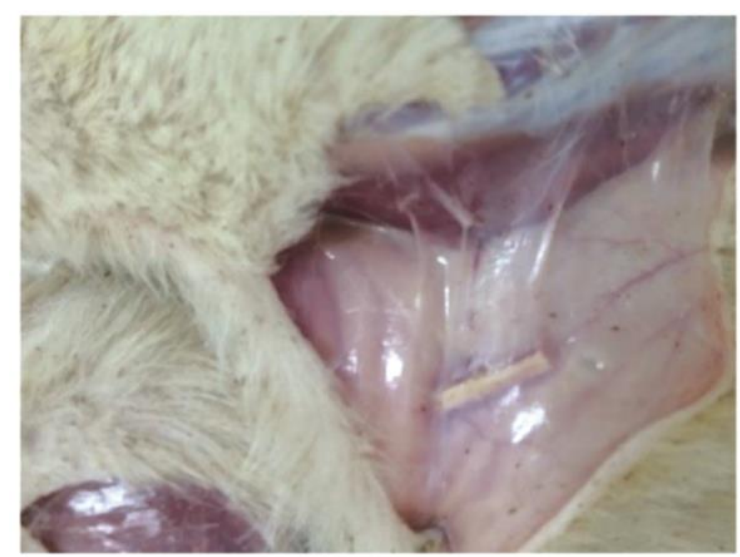

C

Fig. 3. Subcutaneous introduction: a - sample 1 ( $0 \%$ of doped calcium carbonate phosphate); $\mathrm{b}$ - sample 2 (5\% of doped calcium carbonate phosphate); c) - sample 3 (10\% of doped calcium carbonate phosphate)

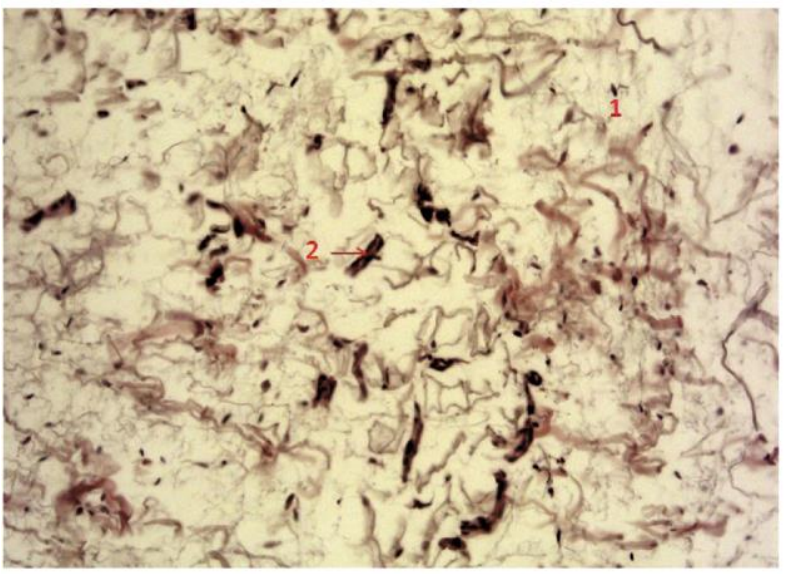

a

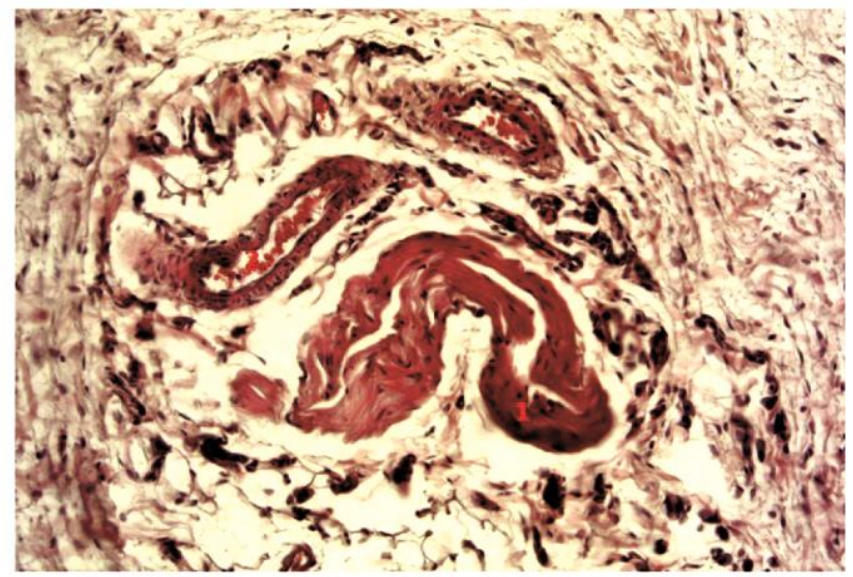

$\mathrm{b}$

Fig. 4. Connective tissue formed around the sample of doped nanocrystalline calcium carbonate phosphates: a - loose connective tissue with functionally active fibroblasts (1), sinusoidal capillaries (2); b - focus of dense fibrous tissue (1), vessel (2) 


\section{References}

1. Hench L.L. Bioceramics. Journal of the American Ceramic Society, 1998, vol. 81 (7), pp. 1705-1728. DOI: 10.1111/j.1151-2916.1998.tb02540.x.

2. Hench L.L. Chronology of bioactive glass development and clinical applications. New Journal of Glass and Ceramics, 2013, vol. 3, pp. 67-73. DOI: 10.4236/njgc.2013.32011.

3. Suchanek W., Yashimura M. Processing and properties of hydroxyapatite-based biomaterials for use as hard tissue replacement implants. Journal of Materials Research, 1998, vol. 13, iss. 1, pp. 94-117. DOI: https://doi.org/10.1557/JMR.1998.0015.

4. Azizeh-Mitra Yousefi, Hassane Oudadesse, Rosa Akbarzadeh, Eric Wers and Anita LucasGirot. Physical and biological characteristics of nanohydroxyapatite and bioactive glasses used for bone tissue engineering. Nanotechnol. Rev., 2014, vol. 3 (6), pp. 527-552. DOI: 10.1515/ntrev2014-0013.

5. Wang H., Zuo Y., Zou Q., Cheng L., Huang D., Wang L., Li Yu. Nano-hydroxyapatite/polyamide66 composite tissue-engineering scaffolds with anisotropy in morphology and mechanical behaviors. J. Polym. Sci. Part A: Polym. Chem., 2009, vol. 47, iss. 3, pp. 658-669. DOI: $10.1002 /$ pola.23171.

6. Okamoto M., John B. Synthetic biopolymer nanocomposites for tissue engineering scaffolds. Progress in Polymer Science, 2013, vol. 38, pp. 1487-1503. DOI: 10.1016/j.progpolymsci.2013.06.001.

7. Shamray V.F., Sirotinkin V.P., Smirnov I.V., Kalita V.I., Fedotov A.Yu., Barinov S.M., Komlev V.S. Structure of the hydroxyapatite plasma-sprayed coatings deposited on preheated titanium substrates. Ceramics International, 2017, 43, pp. 9105-9109. DOI: 10.1016/j.ceramint.

8. Shapiro Jenna M., and Oyen Michelle L. Hydrogel Composite Materials for Tissue Engineering Scaffolds. JOM: the Journal of the Minerals, Metals \& Materials Society, 2013, vol. 65 (4), pp. 505-517. DOI: 10.1007/s11837-013-0575-6.

9. Kalita V.I., Mamaev A.I., Mamaeva V.A., Malanin D.A., Komlev D.I., Gnedovets A.G., Novochadov V.V., Komlev V.S., and Radyuk A.A. Structure and shear strength of implants with plasma coatings. Inorganic Materials: Applied Research, 2016, vol. 7, no. 3, pp. 376-387. DOI: $10.1134 / \mathrm{S} 2075113316030102$.

10. Poinern Gérrard Eddy Jai, Brundavanam Sridevi, Fawcett Derek. Biomedical Magnesium Alloys: A Review of Material Properties, Surface Modifications and Potential as a Biodegradable Orthopaedic Implant. American Journal of Biomedical Engineering, 2012, 2 (6), pp. 218-240. DOI: $10.5923 /$ j.ajbe.20120206.02.

11. Sadeghzade Sorour, Emadi Rahmatollah, Tavangarian Fariborz, Naderi Mozhgan. Fabrication and evaluation of silica-based ceramic scaffolds for hard tissue engineering applications. Materials Science and Engineering C, 2017, 71, pp. 431-438. DOI: 10.1016/j.msec.2016.10.042.

12. Koroleva L.F. Nanocrystalline Doped Calcium Carbonate-Phosphates as a Biomaterial for Osteogenesis. Research Journal of Pharmaceutical, Biological and Chemical Sciences, 2014, 5 (6), pp. 704-710.

13. Savelyeva Maria S., Abalymov Anatoly A., Lyubun German P., Vidyasheva Irina V., Yashchenok Alexey M., Douglas Timothy E. L., Gorin Dmitry A., Parakhonskiy Bogdan V. Vaterite coatings on electrospun polymeric fibers for biomedical applications. Journal of Biomedical Materials Research: Part. A., 2017, vol. 105, iss. 1, pp. 94-103. DOI: 10.1002/jbm.a.35870 .

14. Koroleva L. F. Doped Nanocrystalline Calcium Carbonate Phosphates. Inorganic Materials, 2010, vol. 46, no. 4, pp. 405-411. DOI: 10.1134/S0020168510040151.

15. Koroleva L.F. An Oscillating Mechanism in the Synthesis of Doped Nanocrystalline Calcium Carbonate Phosphates. Nanotechnologies in Russia, 2010, vol. 5, nos. 9-10, pp. 635-640. DOI: 10.1134/S1995078010090077.

16. Koroleva L.F., Larionov L.P., Gorbunova N.P. Doped Calcium Carbonate-Phosphate- Based Biomaterial for Active Osteogenesis. In: Osteogenesis, Yunfeng Lin (ed.), ch. 5, InTech, 2012, pp. 117-134. 
ISBN 978-953-51-0030-0. Available from: http://www.intechopen.com/books/osteogenesis/dopedcalcium-carbonate-phosphatebased-biomaterial-for-active-osteogenesis

17. Koroleva L.F., Larionov L.P., Gorbunova N.P. Biomaterial based on doped calcium carbonate-phosphate for Active Osteogenesis. Journal of Biomaterials and Nanobiotechnology, 2012, no. 3, pp. 226-237. - DOI:10.4236/jbnb.2012.32028.

18. Koroleva L.F., Cherednichenko N.V., Dobrinskaya M.N. Doped Nanocrystalline Calcium Carbonate- Phosphate-Biomaterial with Transdermal Activity for Osteogenesis, ch. 9, pp. 231-247. In: Naveen Navani Kumar and Sinha Shishir, Nanotechnology, vol. 11: Biomaterials, STUDIUM PRESS LLC. USA-India, 2013, 484 p. ISBN: 1-626990-11-5.

19. Koroleva L.F. Dobrinskaya M.N. Kamantsev I.S. Doped calcium carbonate-phosphate used for bone tissue technology. Integrative Clinical Medicine, 2017, vol. 1 (2), pp. 1-7. DOI: 10.15761/ICM.1000108. ISSN: 2515-0219.

20. Koroleva L.F. Oscillating reactions in the synthesis of doped nanocrystalline calcium carbonate phosphates of transdermal ability. Biointerface Research in Applied Chemistry, 2014, vol. 4, iss. 6, pp. 1-4. ISSN 2069-5837.

21. Koroleva L.F., Dobrinskaya M.N., Kamantsev I.S. Doped nanocrystalline calcium carbonatephosphate - a biomaterial for bone repair and strengthening by drug delivery. Diagnostics, Resource and Mechanics of materials and structure, 2015, iss. 5, pp. 147-152. DOI: 10.17804/24109908.2015.5.147-157. Available at: http://dream-journal.org/issues/2015-5/2015-5_40.html 